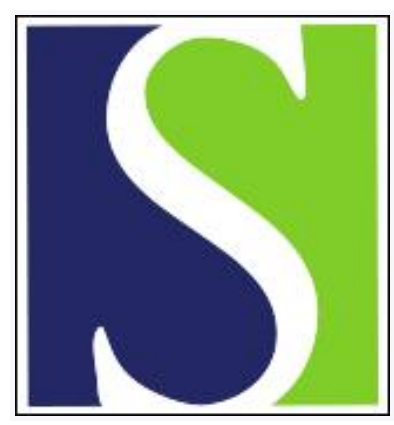

Scand J Work Environ Health 1996;22(4):260-266

https://doi.org/10.5271/sjweh.140

Issue date: Aug 1996

Dietary intake of fish contaminated with persistent organochlorine compounds in relation to low birthweight

by Rylander L, Strömberg U, Hagmar L

Key terms: birthweight; case-referent study; contamination; dietary intake; fish; fish consumption; PCP; persistent organochlorine compound; polychlorinated dibenzo-p-dioxin; polychlorinated dibenzofuran

This article in PubMed: www.ncbi.nlm.nih.gov/pubmed/8881014 


\title{
Dietary intake of fish contaminated with persistent organochlorine compounds in relation to low birthweight
}

\author{
by Lars Rylander, BSc, ${ }^{1}$ Ulf Strömberg, PhD, ${ }^{1}$ Lars Hagmar, $M D^{1}$
}

\begin{abstract}
Rylander L, Strömberg U, Hagmar L. Dietary intake of fish contaminated with persistent organochlorine compounds in relation to low birthweight. Scand J Work Environ Health 1996;22:260-6.

Objectives The purpose of this study was to assess the hypothesized association between persistent organochlorine compounds through the consumption of fatty fish from the Baltic Sea (at the Swedish east coast) and low birthweight.

Materials and methods During the period 1973 - 1991, 72 cases of low birthweight $(1500$ - 2750 g) were selected from among infants born to fishermen's wives within a cohort from the Swedish east coast. For each case two referents were selected. The mothers were interviewed about their dietary and smoking habits and place of living during childhood and adolescence.

Results A high total current intake of fish from the Baltic Sea ( $\geq 4$ meals per month) tended to increase the risk of having an infant with low birthweight [adjusted odds ratio (OR) 1.9, 95\% confidence interval (95\% CI) 0.9 3.9]. The effect was more conspicuous for the boys (OR 3.4, 95\% CI 1.1-11). No such effects were observed when the estimated intake of fish was considered for the period in which the infant was born. However, mothers who had grown up in a fishing village had an increased risk of having an infant with low birthweight (OR 2.1, 95\% CI 1.0-4.3).

Conclusions The variable "grown up in a fishing village" can be interpreted as an indirect measure of a mother's accumulated consumption of fish from the Baltic Sea. This idea supports an association between a high consumption of contaminated fish from the Baltic Sea and an increased risk for low birthweight. The effect estimates based on the mothers' reported fish consumptions were dependent on the period under consideration and therefore were somewhat ambiguous.
\end{abstract}

Key terms case-referent study, fish consumption, polychlorinated biphenyls, polychlorinated dibenzo p-dioxins and furans.

Prenatal exposure to polychlorinated biphenyls (PCB) has caused reduced birthweight and neurodevelopmental disturbances in litters in experimental animal studies (14). Infants born to mothers who consumed large quantities of rice oil contaminated with PCB and polychlorinated dibenzofurans (PCDF) suffered from intrauterine growth retardation (5-8). Moreover, for infants born to mothers with substantially lower exposure levels through the consumption of fish contaminated with PCB, possible associations with low birthweight and poorer cognitive and psychomotor development have been reported $(9-12)$.

In Sweden a main exposure route for $\mathrm{PCB}$ and other persistent organochlorine compounds, such as PCDF, polychlorinated dibenzo- $p$-dioxins (PCDD), and dichlorodiphenyltrichloroethane (DDT), is through the consumption of fatty fish from the Baltic Sea (or the Swedish east coast) (13-15). In a cohort of women married to fishermen from the Swedish east coast, infants born during the period 1973-1991 more frequently had a low birthweight when compared with infants born to a corresponding cohort of women from the Swedish west coast (Kattegatt and Skagerrak), where the fish is less contaminated (16). This effect was more conspicuous when the analyses were restricted to male offspring, as well as to heavy smokers. Dietary interviews with a small random sample of the cohort women indicated a higher intake of locally caught fish in both cohorts, compared with women from the general Swedish population. Smoking habits were only known from 1982 on (for about $40 \%$ of the mothers). Thus, in our preceding cohort study, there was a considerable lack of information on individual dietary and smoking habits.

The objective of the present case-referent study, performed within the cohort of the east-coast women, was to investigate the hypothesized association between die-

1 Department of Occupational and Environmental Medicine, University Hospital, Sweden.

Reprint requests to: Mr L Rylander, Department of Occupational and Environmental Medicine, University Hospital, S-221 85 Lund, Sweden. 
tary intake of persistent organochlorine compounds through the consumption of fatty fish from the Baltic Sea and low birthweight.

\section{Subjects and methods}

\section{Study base}

By linkage to the national Swedish population register and to the registers at the local parish offices, a cohort of women who were, or had been, married to fishermen from the Swedish east coast was established (16). The women in the cohort were linked to the Swedish Medical Birth Register, which includes almost every infant born in Sweden since 1973 and comprises information on, for example, birthweight (17).

\section{Cases}

During the period 1973 - 1991 cases were selected from the infants born in the cohort according to the following criterion: a single birth infant with a birthweight in the interval $1500-2750 \mathrm{~g}$ and without major malformation. Moreover, if a mother had given birth to more than one infant with low birthweight, only the one born first was eligible as a case. These criteria resulted in 90 potential cases. One of the mothers had died, and the case was therefore excluded. Seventy-two women (81\%) agreed to participate in the study. Almost half of the mothers were primiparas $(47 \%$, table 1). Forty-seven percent of the infants were boys, and the median birthweight was $2450 \mathrm{~g}$.

\section{Referents}

For each case two referents were randomly selected from the cohort. The referents were infants with birthweights between 3250 and $4500 \mathrm{~g}$, considered to be an appropriate interval of normal birthweight. The referents were matched to the cases according to gender, parity $(1,2$ and $\geq 3$ ), and calendar year of birth ( \pm 5 years). An infant could only be a referent for one case. One of the mothers claimed she had not been married to a fisherman and was therefore excluded. There were 162 mothers (92\%) who agreed to participate in the study. The referents' median birthweight was $3680 \mathrm{~g}$ (table 1). Due to the nonparticipant cases, 30 referents were reallocated according to the matching criteria. This procedure resulted in 1 matched set with one referent, 55 sets with two referents, 13 sets with three referents, and 3 sets with four referents.

\section{Exposure assessment}

Telephone interviews were performed with the mothers during May and June 1994 by one interviewer, who was not aware of the pregnancy outcome. Moreover, the in- terviewed mothers had not been informed that they had been selected due to their pregnancy outcome. This procedure was approved by the Ethical Committee of the Medical Faculty of Lund University. The questionnaires were distributed to the mothers beforehand, together with color pictures of three different sizes of four fish species. It was not possible to reach 10 cases and 9 referents by telephone; however, their questionnaires were returned by mail.

The mothers were asked to estimate their consumption of lean and fatty fish from the Baltic Sea (meals per month) at different time periods. (See the appendix.) From color pictures of different sizes of fish portions, the current amounts consumed were estimated, according to a previous approach (14). Moreover, the mothers were asked if they had grown up in a fishing village.

\section{Potential confounders}

The current (an average of the last year) food frequencies for several other food items, as well as coffee and alcohol consumption, were assessed. The mothers were also asked about their food frequencies today compared with $10-20$ years ago. Detailed data on the mothers' smoking habits were obtained (ie, their "start" and "stop" year of smoking and average daily consumption). In addition,

Table 1. Background characteristics of the cases and referents.

\begin{tabular}{|c|c|c|c|c|}
\hline \multirow[t]{2}{*}{ Characteristic } & \multicolumn{2}{|c|}{$\begin{array}{l}\text { Cases } \\
(N=72)^{\mathrm{a}}\end{array}$} & \multicolumn{2}{|c|}{$\begin{array}{l}\text { Referents } \\
(\mathrm{N}=162)^{\mathrm{b}}\end{array}$} \\
\hline & $N$ & $\%$ & $N$ & $\%$ \\
\hline \multicolumn{5}{|l|}{ Calendar year of birth } \\
\hline $\begin{array}{l}1973-1978 \\
1979-1984 \\
1985-1991\end{array}$ & $\begin{array}{l}29 \\
18 \\
25\end{array}$ & $\begin{array}{l}40 \\
25 \\
35\end{array}$ & $\begin{array}{l}65 \\
43 \\
54\end{array}$ & $\begin{array}{l}40 \\
27 \\
33\end{array}$ \\
\hline \multicolumn{5}{|l|}{ Parity } \\
\hline $\begin{array}{l}1 \\
2 \\
\geq 3\end{array}$ & $\begin{array}{l}34 \\
18 \\
20\end{array}$ & $\begin{array}{l}47 \\
25 \\
28\end{array}$ & $\begin{array}{l}72 \\
40 \\
50\end{array}$ & $\begin{array}{l}44 \\
25 \\
31\end{array}$ \\
\hline \multicolumn{5}{|l|}{ Maternal age } \\
\hline $\begin{array}{l}\leq 19 \text { years } \\
20-24 \text { years } \\
25-29 \text { years } \\
30-34 \text { years } \\
\geq 35 \text { years }\end{array}$ & $\begin{array}{r}2 \\
24 \\
19 \\
17 \\
10\end{array}$ & $\begin{array}{r}3 \\
33 \\
26 \\
24 \\
14\end{array}$ & $\begin{array}{r}5 \\
38 \\
66 \\
37 \\
16\end{array}$ & $\begin{array}{r}3 \\
23 \\
41 \\
23 \\
10\end{array}$ \\
\hline \multicolumn{5}{|l|}{ Gestational length } \\
\hline $\begin{array}{l}\leq 33 \text { weeks } \\
34-37 \text { weeks } \\
38-40 \text { weeks } \\
\geq 41 \text { weeks } \\
\text { Unknown }\end{array}$ & $\begin{array}{r}8 \\
26 \\
27 \\
6 \\
5\end{array}$ & $\begin{array}{r}12 \\
39 \\
40 \\
9\end{array}$ & $\begin{array}{r}1 \\
2 \\
95 \\
49 \\
15\end{array}$ & $\begin{array}{r}1 \\
1 \\
65 \\
33\end{array}$ \\
\hline Male gender & 34 & 47 & 74 & 46 \\
\hline \multicolumn{5}{|c|}{$\begin{array}{l}\text { Smoking habits during the year } \\
\text { of childbirth }\end{array}$} \\
\hline $\begin{array}{l}0 \text { cigarettes a day } \\
1-9 \text { cigarettes a day } \\
\geq 10 \text { cigarettes a day } \\
\text { Unknown }\end{array}$ & $\begin{array}{r}28 \\
2 \\
40 \\
2\end{array}$ & $\begin{array}{r}40 \\
3 \\
57\end{array}$ & $\begin{array}{r}81 \\
18 \\
62 \\
1\end{array}$ & $\begin{array}{l}50 \\
11 \\
39\end{array}$ \\
\hline
\end{tabular}

a Birthweight $(g)$ : median of 2450 , range of $1530-2740$.

b Birthweight (g): median of 3680 , range of $3250-4490$. 
questions were asked concerning the mothers' educational level.

\section{Statistics}

The odds ratio (OR), adjusted for potential confounders, was used for measuring the effect of fish consumption on low birthweight. The effect estimation was performed by means of conditional logistic regression (18). For statistical testing we also used Fisher's exact test for binary variables, and the Mann-Whitney test for continuous variables. All the tests were two-tailed.

\section{Results}

Univariate logistic regression analyses did not indicate an effect of current intake of meat, sausage, chicken, vegetables, fruits, milk, coffee, or alcohol (all P-values greater than 0.15 , likelihood ratio tests) on birthweight. Moreover, the educational level was similar for the mothers in the case and reference groups. A higher proportion of the case mothers smoked during the year of childbirth (table 1).

Adjusted for maternal age ( $\leq 24,25-29, \geq 30$ years) and smoking habits during the year of childbirth $(0-9$ and $\geq 10$ cigarettes a day), a total current intake of fish from the Baltic Sea of at least four meals per month versus less intake indicated an increased risk of having an infant with low birthweight (OR 1.9, 95\% CI $0.9-$ 3.9). There was, however, no clear dose-response rela- tionship (table 2). The same pattern was seen concerning the total current amount consumed ( $>600 \mathrm{~g}$ a month versus less: OR $2.1,95 \%$ CI $1.0-4.3$ ). The OR values were not enhanced further when only the consumption of fatty fish was considered (table 2).

In contrast to the results for current consumption, the estimated intake of fish from the Baltic Sea during the time period in which the infant was born (for definition, see the appendix) did not imply increased OR values (table 3).

When the analyses were restricted to boys, the comparison between a total current intake of at least four Baltic Sea fish meals per month versus less intake gave an OR of 3.4 (95\% CI 1.1-11). For the total current amount consumed, the OR was 3.7 (95\% CI 1.1-12) for $>600 \mathrm{~g}$ a month, as compared with less intake. The OR values were less enhanced when only the consumption of fatty fish was taken into account (table 2). For the boys, increased $O R$ values were indicated also as regards the fish consumption during the period in which the infant was born, whereas, for the girls, decreased OR values were observed (table 3).

Twenty-five percent of the case mothers had grown up in a fishing village as compared with $15 \%$ of the reference mothers. After adjustment for maternal age and smoking habits during year of childbirth, the effect of growing up in a fishing village was still pronounced (OR 2.1, 95\% CI 1.0-4.3). This risk estimate did not differ between the male and female offspring.

When we included the indicator "grown up in a fishing village" in the model together with each of the vari-

Table 2. Distribution of the case mothers and the reference mothers according to their current consumption of fish from the Baltic Sea.

\begin{tabular}{|c|c|c|c|c|c|c|c|c|c|c|c|}
\hline \multirow[t]{2}{*}{ Fish consumption } & \multicolumn{2}{|c|}{ Cases } & \multicolumn{2}{|c|}{ Referents } & Boys & \multicolumn{2}{|c|}{ Girls } & \multicolumn{4}{|c|}{ All } \\
\hline & $\begin{array}{c}\text { Total } \\
\text { number }\end{array}$ & $\begin{array}{l}\text { Number } \\
\text { of boys }\end{array}$ & $\begin{array}{c}\text { Total } \\
\text { number }\end{array}$ & $\begin{array}{l}\text { Number } \\
\text { of boys }\end{array}$ & $\begin{array}{c}\text { Adjusted } 95 \% \mathrm{Cl} \\
\mathrm{OR}^{\mathrm{a}} \text { of adjusted } \\
\text { OR }\end{array}$ & $\begin{array}{l}\text { Adjusted } \\
\mathrm{OR}^{\mathrm{a}}\end{array}$ & $\begin{array}{c}95 \% \mathrm{Cl} \\
\text { of adjusted } \\
\text { OR }\end{array}$ & $\begin{array}{c}\text { Crude } \\
\text { OR }\end{array}$ & $\begin{array}{l}95 \% \mathrm{Cl} \\
\text { of crude } \\
\text { OR }\end{array}$ & $\begin{array}{l}\text { Adjusted } \\
O \mathrm{R}^{\mathrm{a}}\end{array}$ & $\begin{array}{l}95 \% \mathrm{Cl} \\
\text { of adjusted } \\
\text { OR }\end{array}$ \\
\hline
\end{tabular}

\begin{tabular}{|c|c|c|c|c|c|c|c|c|c|c|c|c|}
\hline \multicolumn{13}{|l|}{ Meals per month } \\
\hline \multicolumn{13}{|l|}{ Fatty fish } \\
\hline $\begin{array}{l}0 \\
1-3 \\
\geq 4\end{array}$ & $\begin{array}{l}21 \\
34 \\
17\end{array}$ & $\begin{array}{r}8 \\
18 \\
8\end{array}$ & $\begin{array}{l}56 \\
64 \\
42\end{array}$ & $\begin{array}{l}25 \\
33 \\
16\end{array}$ & $\begin{array}{l}1.0 \\
2.1 \\
2.7\end{array}$ & $\begin{array}{l}0.7-6.5 \\
0.8-9.6\end{array}$ & $\begin{array}{l}1.0 \\
1.9 \\
0.9\end{array}$ & $\begin{array}{l}0.7-4.9 \\
0.3-2.8\end{array}$ & $\begin{array}{l}1.0 \\
1.3 \\
1.1\end{array}$ & $\begin{array}{c}{ }^{*} \\
0.7-2.5 \\
0.5-2.3\end{array}$ & $\begin{array}{l}1.0 \\
1.7 \\
1.4\end{array}$ & $\begin{array}{c}. " \\
0.8-3.4 \\
0.6-3.1\end{array}$ \\
\hline \multicolumn{13}{|l|}{ Total } \\
\hline $\begin{array}{l}0-3 \\
4-6 \\
\geq 7\end{array}$ & $\begin{array}{l}17 \\
27 \\
28\end{array}$ & $\begin{array}{r}6 \\
15 \\
13\end{array}$ & $\begin{array}{l}57 \\
46 \\
59\end{array}$ & $\begin{array}{l}29 \\
21 \\
24\end{array}$ & $\begin{array}{l}1.0 \\
3.4 \\
3.4\end{array}$ & $\begin{array}{l}0.8-14 \\
1.0-12\end{array}$ & $\begin{array}{l}1.0 \\
1.8 \\
1.2\end{array}$ & $\begin{array}{c}. \cdot \\
0.6-5.3 \\
0.4-3.4\end{array}$ & $\begin{array}{l}1.0 \\
2.0 \\
1.6\end{array}$ & $\begin{array}{c}. . \\
0.9-4.1 \\
0.8-3.4\end{array}$ & $\begin{array}{l}1.0 \\
2.0 \\
1.8\end{array}$ & $\begin{array}{l}0.9-4.5 \\
0.9-4.0\end{array}$ \\
\hline \multicolumn{13}{|l|}{ Grams per month } \\
\hline $\begin{array}{l}0 \\
1-500 \\
>500\end{array}$ & $\begin{array}{l}21 \\
27 \\
24\end{array}$ & $\begin{array}{r}8 \\
14 \\
12\end{array}$ & $\begin{array}{l}56 \\
47 \\
59\end{array}$ & $\begin{array}{l}25 \\
24 \\
25\end{array}$ & $\begin{array}{l}1.0 \\
2.2 \\
2.4\end{array}$ & $\begin{array}{l}0.7-7.3 \\
0.8-7.6\end{array}$ & $\begin{array}{l}1.0 \\
2.2 \\
0.9\end{array}$ & $\begin{array}{c}\cdot . \\
0.8-6.2 \\
0.3-2.5\end{array}$ & $\begin{array}{l}1.0 \\
1.4 \\
1.1\end{array}$ & $\begin{array}{c}. . \\
0.7-2.7 \\
0.5-2.2\end{array}$ & $\begin{array}{l}1.0 \\
2.0 \\
1.2\end{array}$ & $\begin{array}{c}. " \\
0.9-4.1 \\
0.6-2.6\end{array}$ \\
\hline \multicolumn{13}{|l|}{ Total } \\
\hline $\begin{array}{l}0-600 \\
601-1700 \\
>1700\end{array}$ & $\begin{array}{l}16 \\
33 \\
23\end{array}$ & $\begin{array}{r}6 \\
15 \\
13\end{array}$ & $\begin{array}{l}57 \\
48 \\
57\end{array}$ & $\begin{array}{l}28 \\
21 \\
25\end{array}$ & $\begin{array}{l}1.0 \\
4.0 \\
3.5\end{array}$ & $\begin{array}{c}. . \\
1.0-17 \\
1.0-12\end{array}$ & $\begin{array}{l}1.0 \\
2.1 \\
1.1\end{array}$ & $\begin{array}{c}. \cdot \\
0.7-6.3 \\
0.4-3.4\end{array}$ & $\begin{array}{l}1.0 \\
2.5 \\
1.5\end{array}$ & $\begin{array}{c}. . \\
1.2-5.3 \\
0.7-3.3\end{array}$ & $\begin{array}{l}1.0 \\
2.5 \\
1.8\end{array}$ & $\begin{array}{c}. . \\
1.1-5.6 \\
0.8-4.0\end{array}$ \\
\hline
\end{tabular}

\footnotetext{
a Odds ratio adjusted for maternal age ( 3 categories: $\leq 24,25-29$, and $\geq 30$ years) and smoking habits during the calendar year of birth ( 2 categories: 0 9 and $\geq 10$ cigarettes a day).
} 
Table 3. Distribution of the case mothers and the reference mothers according to their estimated consumption of fish from the Baltic Sea during the period in which the infant was born.

\begin{tabular}{|c|c|c|c|c|c|c|c|c|c|c|}
\hline \multirow[t]{2}{*}{ Fish consumption } & \multicolumn{2}{|c|}{ Cases } & \multicolumn{2}{|c|}{ Referents } & Boys & Girls & \multicolumn{4}{|c|}{ All } \\
\hline & $\begin{array}{l}\text { Total } \\
\text { number }\end{array}$ & $\begin{array}{l}\text { Number } \\
\text { of boys }\end{array}$ & $\begin{array}{l}\text { Total } \\
\text { number }\end{array}$ & $\begin{array}{l}\text { Number } \\
\text { of boys }\end{array}$ & $\begin{array}{c}\text { Adjusted } 95 \% \mathrm{Cl} \\
0 \mathrm{R}^{\mathrm{a}} \text { of adjusted } \\
\text { OR }\end{array}$ & $\begin{array}{c}\text { Adjusted } 95 \% \mathrm{Cl} \\
0 \mathrm{R}^{\mathrm{a}} \text { of adjusted } \\
\text { OR }\end{array}$ & $\begin{array}{c}\text { Crude } \\
\text { OR }\end{array}$ & $\begin{array}{l}95 \% \mathrm{Cl} \\
\text { of crude } \\
\text { OR }\end{array}$ & $\begin{array}{l}\text { Adjusted } \\
\mathrm{OR}^{\mathrm{a}}\end{array}$ & $\begin{array}{l}95 \% \mathrm{Cl} \\
\text { of adjusted } \\
\text { OR }\end{array}$ \\
\hline
\end{tabular}

\begin{tabular}{|c|c|c|c|c|c|c|c|c|c|c|c|c|}
\hline \multicolumn{13}{|c|}{ Meals per month } \\
\hline \multicolumn{13}{|l|}{ Fatty fish } \\
\hline $\begin{array}{l}0 \\
1-3 \\
\geq 4\end{array}$ & $\begin{array}{l}25 \\
20 \\
27\end{array}$ & $\begin{array}{r}8 \\
11 \\
15\end{array}$ & $\begin{array}{l}45 \\
60 \\
57\end{array}$ & $\begin{array}{l}18 \\
32 \\
24\end{array}$ & $\begin{array}{l}1.0 \\
1.0 \\
1.6\end{array}$ & $\begin{array}{c}{ }^{\prime} \\
0.3-2.9 \\
0.5-5.0\end{array}$ & $\begin{array}{l}1.0 \\
0.6 \\
0.7\end{array}$ & $\begin{array}{l}. \cdot \\
0.2-1.8 \\
0.2-1.8\end{array}$ & $\begin{array}{l}1.0 \\
0.6 \\
0.9\end{array}$ & $\begin{array}{c}. . \\
0.3-1.3 \\
0.5-1.8\end{array}$ & $\begin{array}{l}1.0 \\
0.7 \\
0.9\end{array}$ & $\begin{array}{c}0 . \\
0.3-1.3 \\
0.4-1.8\end{array}$ \\
\hline \multicolumn{13}{|l|}{ Total } \\
\hline $\begin{array}{l}0-3 \\
4-6 \\
\geq 7\end{array}$ & $\begin{array}{l}20 \\
17 \\
35\end{array}$ & $\begin{array}{r}5 \\
13 \\
16\end{array}$ & $\begin{array}{l}34 \\
47 \\
81\end{array}$ & $\begin{array}{l}17 \\
20 \\
37\end{array}$ & $\begin{array}{l}1.0 \\
1.9 \\
1.4\end{array}$ & $\begin{array}{c}0.5-7.5 \\
0.4-4.9\end{array}$ & $\begin{array}{l}1.0 \\
0.2 \\
0.5\end{array}$ & $\begin{array}{c}0.04-0.7 \\
0.2-1.4\end{array}$ & $\begin{array}{l}1.0 \\
0.6 \\
0.8\end{array}$ & $\begin{array}{c}. " \\
0.3-1.3 \\
0.4-1.5\end{array}$ & $\begin{array}{l}1.0 \\
0.6 \\
0.7\end{array}$ & $\begin{array}{c}. \cdot \\
0.3-1.5 \\
0.3-1.4\end{array}$ \\
\hline
\end{tabular}

a Odds ratio adjusted for maternal age ( 3 categories: $\leq 24,25-29$, and $\geq 30$ years) and smoking habits during the calendar year of birth ( 2 categories: $0-$ 9 and $\geq 10$ cigarettes a day).

ous measures of fish consumption, the estimates changed only slightly.

\section{Discussion}

In the present study mothers who reported a high current intake of fish from the Baltic Sea, as well as mothers who had grown up in a fishing village, had an increased risk of having an infant with low birthweight. On the other hand, considering the estimated intake of fish during the period in which the infant was born, no such effect was observed.

The response rate was somewhat lower for the case mothers than for the reference mothers, and therefore selection bias was possible. The fraction of women divorced from fisherman was equal among the participant case and reference mothers (19\% in both groups), whereas a much higher proportion of the nomparticipant mothers was divorced $(59 \%$ and $47 \%$ of the case and reference mothers, respectively). The age distributions were similar for the participant and nonparticipant mothers, and also for the nonparticipant case and reference mothers. We do not therefore believe that selection bias is an issue of major concern.

The quality of birthweight data has been good in the Swedish Medical Birth Register (17). Thus misclassification of the outcome variable was not a problem in this study. On the other hand, misclassification of exposure is an issue of concern. To diminish the risk of recall bias, we did not inform the responders that they had been selected due to their pregnancy outcome. In addition, at the end of the interview the mothers were asked if they were aware of the ongoing debate in the media concerning the consumption of fish from the Baltic Sea and possible associations with health hazards. Only 5\% of the case and the reference mothers were aware of a possible risk with respect to pregnancy outcome. Thus it seems improbable that recall bias has affected the present results. We should add that the telephone interviews were made by one interviewer who was not aware of the pregnancy outcomes. A larger fraction of the case mothers had sent their questionnaires by mail, and adjustment for this in the analyses did not affect the results.

Maternal ages and smoking habits are well known risk factors for low birthweight (19) and were therefore adjusted for in the models. Smoking status during late pregnancy is a more important risk factor than smoking status during early pregnancy (20). Only three of the case mothers and three of the reference mothers stated that they had quit smoking during the birth year of their infant. Thus it is reasonable to assume that the smoking data in this study reflect the smoking habits during late pregnancy. In the category of mothers who smoked at least 10 cigarettes per day, the mean number of cigarettes per day did not differ between the case and reference mothers ( 17 versus 15 cigarettes a day). The maternal smoking habits during the birth year of the infants were dichotomized in the analyses, and the maternal age was trichotomized. Other classifications did not noticeably affect the results.

Available data on height from the Medical Birth Register did not show any difference between the case and the reference mothers [median heights (quattiles) were $167(162,172) \mathrm{cm}$ and $164(161,170) \mathrm{cm}$, based on 21 and 59 subjects, respectively], and do not support the idea that body height had influenced the risk for low birthweight. Moreover, the height of mothers is considered to be a weak predictor of birthweight (16).

The main exposure route for PCB is through the consumption of fatty fish from the Baltic Sea. However, the OR values were somewhat lower for the current consumption of fatty fish in the present study, as compared with the total consumption. One reason for the 
lower OR values may be a higher degree of misclassification of fatty than of total fish consumption.

Organochlorine compounds are persistent and accumulate in the body throughout a life-time. A reasonable agreement between the estimated current consumption of fish from the Baltic Sea and blood levels of PCDD, PCDF, and PCB has been shown previously $(13,15)$. The current consumption among the mothers is probably a measure with relatively good precision, but it is obviously not the most relevant with respect to the birthweight of the infants. The fish consumption during the period when the infant was born, estimated through the dietary interviews, may be a more adequate measure. There is, however, an obvious negative impact on the precision of this measure by the need to recall dietary habits years ago, and by the assumptions made in the model in order to transform possible frequencies within intervals into fixed frequencies. This problem may thus explain the lack of association between the fish consumption during the period when the infant was born and low birthweight. There seems to have been a slight overall decrease in the consumption of fish from the Baltic Sea during the study period; $29 \%$ of the mothers had decreased and $14 \%$ had increased their dietary intake since the time period when the infant was born. The OR values for low birthweight remained, however, almost the same when separate analyses were performed for the infants born during the periods 1973-1985 and 19861991, respectively.

The variable "grown up in a fishing village" can be interpreted as an indirect measure of high consumption of fish from the Baltic Sea during childhood and adolescence. No direct estimations of the mothers' fish consumption during their childhood was made because the precision of such estimates was considered to be very low. We point out that a greater fraction of the mothers who had grown up in a fishing village had a current intake of at least seven meals per month of fish from the Baltic Sea compared with those who had not grown up in a fishing village $(51 \%$ versus $34 \%, \mathrm{P}=0.05$ ). Hypothetically, the variable "grown up in a fishing village" could also be an indirect measure of the mothers' life-style or socioeconomic status. The fractions of smokers during the calendar years when the infants were born were, however, similar for the mothers who had grown up in a fishing village and those who had not $(51 \%$ versus $53 \%)$. Forty-nine percent of the mothers who had grown up in a fishing village had only a nine-year compulsory school education, as compared with $34 \%$ of the others $(P=0.08)$. A decreased risk for low birthweight has, however, only been observed among women with a university education (21). With respect to this phenomenon, the mothers who had grown up in a fishing village did not differ from the other mothers (16\% versus $19 \%$ ). Thus we tend to conclude that the most reasonable, and biologically relevant, interpretation of the variable "grown up in a fishing village" is that it reflects high fish consumption during childhood and adolescence.

Employing separate analyses for infants small for their gestational age [as defined by Pradat (22); also described in reference 16] and preterm (<37 weeks) infants, no distinct differences in the OR values were observed, irrespective of whether "grown up in a fishing village" or "estimated fish consumption" was used as the exposure measure. Such a discrimination is, however, difficult to obtain due to the lack of precision of Swedish Medical Birth Register data on gestational length (17).

Prenatal exposures to PCB, through maternal consumption of contaminated fish, have been associated with reduced birthweight in the Lake Michigan area (9). Such exposure may also be an explanation in the present study. In our previous cohort study (16), as well as in the present study, the risk for low birthweight tended to be more conspicuous among the male offspring. However, the results are ambiguous, as the effect estimate for the factor "grown up in a fishing village" was not modified by gender. Among Japanese Yusho mothers who had consumed rice oil contaminated with $\mathrm{PCB}$ and PCDF, the incidence of low birthweight was increased only for female infants (23). On the other hand, the critical in utero dose of 2,3,7,8-tetrachlorodibenzo-p-dioxin (TCCD) causing developmental disturbances in experimental animals is considerably lower for male than for female offspring (24).

A disadvantage of the present study design was the lack of data on blood levels of persistent organochlorine compounds in the mothers. In a random sample of male Swedish east-coast fishermen the blood concentrations of PCDD, PCDF and PCB were two- to threefold higher as compared with those of both referents from the general population within the same geographic area and west-coast fishermen (14). Thus, on a group basis, it is reasonable to assume that similar differences exist for the fishermen's wives. However, there was a large interindividual variation in fish intake within the cohort, and this variation allowed a dose-response analysis concerning birthweight. A further step in this investigation should be to assess the association between individual blood levels of persistent organochlorine compounds in east-coast mothers and the birthweight of their infants.

\section{Acknowledgments}

The authors are indebted to Mr Sven Rylander for performing the telephone interviews. This work was financed by grants from the Swedish National Environmental Protection Board, the Swedish Work Environment Fund, and the Medical Faculty, Lund University. 


\section{References}

1. Peterson RE, Theobald HM, Kimmel GL. Developmental and reproductive toxicity of dioxins and related compounds: crossspecies comparisons. CRC Crit Rev Toxicol 1993;23:283335.

2. Tilson HA, Jacobson JL, Rogan WJ. Polychlorinated biphenyls and developing nervous system: cross-species comparisons. Neurotoxicol Teratol 1990;12:239_48.

3. Seegal RF, Shain W. Neurotoxicity of polychlorinated biphenyls: the role of ortho-substituted congeners in altering neurochemical function. In: Isaacson RL, Jensen KF, editors. The vulnerable brain and environmental risks; vol 2 (Toxins in food). New York (NY): Plenum Press, 1992.

4. Morse DC, Groen D, Veerman M, van Amerongen CJ, Köeter HBWM, Smits-van Proije AE, et al. Interference of polychlorinated biphenyls in hepatic and brain thyroid hormone metabolism in fetal and neonatal rats. Toxicol Appl Pharmacol 1993;122:27-33.

5. Rogan WJ, Gladen BC, Hung K-L, Koong S-L, Shih L-Y, Taylor JS, et al. Congenital poisoning by polychlorinated biphenyls and their contaminants in Taiwan. Science 1988;241: $334-6$.

6. Rogan WJ. PCBs and cola-colored babies: Japan, 1968, and Taiwan, 1979. Teratology 1982;26:259-61.

7. Lai TJ, Chen YC, Chou WJ, Guo YL, Ko HC, Hsu CC. Cognitive development in Yucheng children. Organohalogen Compd 1993;14:247-50.

8. Hsu CC, Hu HF, Lai TJ, Ko HC, Chen YC. Behavior development of Yucheng children as compared to their matched controls. Organohalogen Compd 1993;14:239 _ 42.

9. Fein GG, Jacobson JL, Jacobson SW, Schwartz PM, Dowler JK. Prenatal exposure to polychlorinated biphenyls: effects on birth size and gestational age. J Pediatr 1984;105:315-20.

10. Jacobson JL, Fein GG, Jacobson SW, Schwartz PM, Dowler $\mathrm{JK}$. The transfer of polychlorinated biphenyls (PCBs) and polybrominated biphenyls (PBBs) across the human placenta and into maternal milk. Am J Public Health 1984;74:378-9.

11. Jacobson JL, Jacobson SW, Humphrey HEB. Effects of in utero exposure to polychlorinated biphenyls and related contaminants on cognitive functioning in young children. J Pediatr 1990;116:38-45.

12. Jacobson JL, Jacobson SW, Humphrey HEB. Effects of exposure to PCBs and related compounds on growth and activity in children. Neurotoxicol Teratol 1990;12:319-26.

13. Svensson BG, Nilsson A, Hansson M, Rappe C, Åkesson B Skerfving $\mathrm{S}$. Exposure to dioxins and dibenzofurans through the consumption of fish. N Engl J Med 1991;324:8-12.

14. Svensson B-G, Nilsson A, Jonsson E, Schütz A, Åkesson B, Hagmar L. Fish consumption and exposure to persistent organochlorine compounds, mercury, selenium and methylamines in Swedish fishermen. Scand J Work Environ Health 1995;21: 96-105.

15. Asplund L, Svensson BG, Nilsson A, Eriksson U, Jansson B, Jensen $S$, et al. PCB, p,p'-DDT and p,p'-DDE in human plasma related to fish consumption. Arch Environ Health 1994:49:477-86.

16. Rylander L, Strömberg U, Hagmar L. Decreased birthweight in infants born to women with a high dietary intake of fish contaminated with persistent organochlorine compounds. Scand J Work Environ Health 1995;21;368-75.

17. Cnattingius S, Ericson A, Gunnarskog J, Källén B. A quality study of a medical birth registry. Scand J Soc Med 1990;18: $143-8$.

18. Hosmer DW, Lemeshow S. Applied logistic regression. New York (NY): John Wiley \& Sons Inc, 1989

19. Källén B. Epidemiology of human reproduction. Boca Raton (FL): CRC Press Inc, 1988.

20. Ahlsten G, Cnattingius S, Lindmark G. Cessation of smoking during pregnancy improves foetal growth and reduces infant morbidity in the neonatal period: a population-based prospective study. Acta Peadiatr 1993;82:177 - 81.

21. Ericson $A$, Eriksson $M$, Källén $B$, Zetterström R. Methods for the evaluation of social effects on birth weight - experiences with Swedish population registries. Scand J Soc Med 1993;21: 69-76.

22. Pradat P. Epidemilogical characteristics of major congenital heart defects [dissertation]. Lund (Sweden): Department of Embryology, Lund University, 1994.

23. Yamashita $\mathrm{F}$ and Hayashi M. Fetal PCB syndrome: clinical features, intranterine growth retardation and possible alteration in calcium metabolism. Environ Health Perspect 1985;59:41-5.

24. Brouwer A, Ahlborg UG, Van den Berg M, Birnbaum LS, Boersma ER, Bosveld B, et al. Functional aspects of developmental toxicity of polyhalogenated aromatic hydrocarbons in experimental animals and human infants. Eur J Pharmacol Environ Toxicol Pharmacol Section 1995;293:1-40.

\section{Appendix}

\section{Estimation of fish consumption}

The different measures of frequencies (meals per month) of lean and fatty fish from the Baltic Sea were calculated as follows:

1. The current frequency.

Each mother was asked to estimate her average frequency of the year preceding the interview. 
Low birthweight and dietary intake of persistent organochlorine compounds

2. The frequency five years earlier.

Answer

Ate at least five meals more per month earlier compared with the current frequency

Ate $1-4$ meals more per month earlier

Unchanged

Ate $1-4$ meals less per month earlier

Ate at least five meals less per month earlier
Calculated frequency

5 meals added to the current frequency

2.5 meals added to the current frequency

The current frequency

2.5 meals subtracted from the current frequency

Interpreted as zero consumption

3. The frequency $10-20$ years earlier.

Calculated as above.

4. The frequency during the period in which the infant was born.

If the infant was born during the period $1973-1985$, the estimated frequency $10-20$ years earlier was used.

If the infant was born during the period 1986 - 1991, the estimated frequency five years earlier was used.

In the analyses the exposure measures 1 and 4 were used.

Received for publication: 9 October 1995 